\title{
KEPATUHAN WAJIB PAJAK ORANG PRIBADI USAHA MIKRO, KECIL, DAN MENENGAH DITINJAU DARI TARIF PAJAK, SOSIALISASI PAJAK, SANKSI PAJAK, DAN PEMERIKSAAN PAJAK
}

\author{
Komang Krishna Yogantara ${ }^{1 *}$, Gde Herry Sugiarto Asana ${ }^{2}$, Sarita Vania Clarissa ${ }^{3}$ \\ ${ }^{123}$ Universitas Triatma Mulya, \\ *Corresponding author: krishna.yogantara@triatmamulya.ac.id ${ }^{{ }^{*}}$
}

\section{Abstrak}

Pajak mempunyai peranan penting dalam perekonomian sebagai sumber dana pemerintah terbesar dalam melaksanakan tugas mewujudkan kemakmuran rakyat. Usaha Mikro, Kecil dan Menengah (UMKM) merupakan salah satu sektor yang berpotensi memberikan kontribusi pembayaran pajak yang besar terhadap penerimaan pajak negara. Namun kepatuhan wajib pajak orang pribadi UMKM masih rendah, terutama kepatuhan wajib pajak orang pribadi yang terdaftar di KPP Pratama Gianyar belum mencapai target 70 persen. Penelitian ini bertujuan untuk mengetahui pengaruh tarif pajak, sosialisasi perpajakan, sanksi perpajakan, dan pemeriksaan pajak terhadap kepatuhan wajib pajak orang pribadi Usaha Mikro, Kecil, dan Menengah (UMKM) di Kantor Pelayanan Pajak Pratama (KPP) Gianyar. Sebanyak 100 UMKM Wajib Pajak Orang Pribadi yang terdaftar di Kantor Pelayanan Pajak Pratama (KPP) Gianyar dipilih menjadi responden dengan menggunakan Rumus Slovin. Metode penelitian yang digunakan adalah accidental sampling dengan media angket dan teknis analisis data penelitian ini menggunakan regresi linier berganda. Kesimpulan penelitian ini menunjukkan bahwa tarif pajak, sosialisasi perpajakan, sanksi perpajakan, dan pemeriksaan pajak berpengaruh positif dan signifikan terhadap kepatuhan wajib pajak orang pribadi UMKM di Kantor Pelayanan Pajak Pratama (KPP) Gianyar.

Kata Kunci : Tarif pajak, sosialisasi pajak, sanksi pajak, pemeriksaan pajak

\section{Abstract}

Tax has an important role in the economy as the largest source of government funding in carrying out the task of realizing the prosperity of the people. Micro, Small and Medium Enterprises (MSMEs) are one of the sectors that have the potential to contribute large tax payments to state tax revenues. However, the compliance of personal taxpayer of MSMEs still low, especially the compliance of personal taxpayers who are registered in Pratama Tax Office Gianyar has not reached the target of 70 percent. This study aims to determine the influence of the tax rate, tax socialization, tax sanction, and tax investigation toward the obedience of personal taxpayer of Micro, Small, and Medium Enterprises (MSMEs) at the Pratama Tax Office (KPP) Gianyar. Total of 100 MSMEs personal taxpayers that registered at Pratama Tax Office (KPP) Gianyar were selected to be respondents using the Slovin Formula. The research method that used was accidental sampling with media questionnaires and the technical of analysis data of this study is using multiple linear regression. The conclusion of this study indicate that the tax rate, tax socialization, tax sanction, and tax investigation have positive and significant influence on the obedience of personal taxpayer of MSMEs at Pratama Tax Office (KPP) Gianyar.

Keywords: Tax rate, tax socialization, tax sanction, tax investigation

History:
Received: August 2021
Revised: Oktober 2021
Accepted: November 2021
Published: November 2021




\section{PENDAHULUAN}

Penerimaan Negara dari sektor pajak menjadi salah satu sumber utama bagi pemerintah Indonesia dalam membiayai pelaksanaan pembangunan nasional yang bertujuan untuk meningkatkan kesejahteraan dan kemakmuran masyarakat Indonesia. Penerimaan pajak yang semakin besar dijadikan sebagai suatu wujud kemampuan untuk membiayai kegiatan pembangunan dari seluruh komponen bangsa. Target Anggaran Pendapatan dan Belanja Negara untuk pajak mengalami peningkatan setiap tahunnya, namun hal ini tidak diikuti dengan realisasi yang belum sesuai target.

TABEL 1.1 TARGET DAN REALISASI PENERIMAAN NEGARA SEKTOR PAJAK

\begin{tabular}{llllll}
\hline Tahun & 2015 & 2016 & 2017 & 2018 & 2019 \\
\hline Target & 1294,26 & 1355,2 & 1283,6 & 1424 & 1580 \\
Realisasi & 1060,8 & 1069,9 & 1151,1 & 1315,9 & 1332 \\
\% Realiasi & 81,97 & 78,95 & 89,68 & 92 & 84 \\
\hline
\end{tabular}


Sumber : Badan Pusat Statistik (Data diolah kembali),2020

Tabel 1.1 menunjukkan besarnya target penerimaan pajak dan realisasinya dari tahun 2015

\begin{tabular}{llllrl}
\hline \multirow{4}{*}{ Tahun } & Jumlah UMKM & WPOP UMKM & WPOP & UMKM & Tingkat \\
& yang Terdaftar & Melaporkan & yang & Tidak & Kepatuhan \\
& & MPT & Melaporkan SPT & $(\%)$ \\
\hline
\end{tabular}

sampai

2019

masih

belum

mencapa

i target

100

persen.

Hal ini

menunju

kkan

masih

rendahn

ya peran aktif dari masyarakat Indonesia untuk ikut serta memberikan kontribusinya untuk pendapatan Negara melalui kepatuhan dalam membayarkan kewajiban pajaknya. perpajakannya sesuai dengan ketentuan peraturan perundang-undangan yang berlaku. Kepatuhan wajib pajak dalam membayar pajak dapat mempengaruhi pendapatan Negara, karena apabila tingkat kepatuhan rendah maka akan mempengaruhi tingkat pendapatan Negara (Jenita dan Joana, 2017).

Telah banyak upaya yang dilakukan oleh Direktorat Jendral Pajak untuk mendorong peningkatan penerimaan Negara melalui pajak. Pemerintah juga telah menerbitkan PP No. 46 Tahun 2013 yang sekarang telah diubah menjadi PP No. 23 Tahun 2018, peraturan tersebut mengatur tentang perlakuan pajak penghasilan untuk Usaha Mikro, Kecil, dan Menengah (UMKM). Peraturan ini dikeluarkan pemerintah dengan substansinya adalah pungutan pajak sebesar 0,5 persen dari penghasilan usaha yang diterima atau diperoleh wajib pajak dengan peredaran bruto tidak melebihi Rp4,8 miliar dalam 1 tahun, peraturan ini berlaku mulai $1 \mathrm{Juli}$ 2018. Dengan adanya peraturan baru ini diharapkan dapat memudahkan UMKM untuk menghitung, menyetor dan melaporkan Pajak Penghasilan terutang.

UMKM merupakan unit usaha yang paling dominan di Indonesia, sehingga kontribusi UMKM terhadap PDB setiap tahunnya terus meningkat. Berdasarkan data dari Kementrian Koperasi dan UMKM menunjukkan bahwa UMKM menyumbang pada PDB sebesar 62,57 persen dari total PDB. Besarnya potensi penerimaan pajak dari sektor UMKM ini diharapkan tidak hanya terjadi di tingkat nasional melainkan hingga ketingkat kabupaten, salah satunya adalah Kabupaten Gianyar dengan tingkat kepatuhan pajak yang dapat dilihat pada tabel berikut.

TABEL 1.3

Tingkat Kepatuhan Wajib Pajak Orang Pribadi Umkm Di Kantor Pelayanan Pajak Pratama Gianyar Periode 2015 - 2019 


\begin{tabular}{lllll}
\hline 2015 & 7.323 & 5.186 & 2.137 & 70,8 \\
2016 & 8.540 & 5.287 & 3.253 & 61,9 \\
2017 & 10.393 & 5.241 & 5.151 & 50,4 \\
2018 & 13.409 & 7.509 & 5.900 & 56,0 \\
2019 & 18.102 & 10.801 & 7.301 & 60,0 \\
\hline
\end{tabular}

Sumber : Data diolah kembali,2020

Pada Tabel 1.3 dapat dilihat tingkat kepatuhan wajib pajak UMKM yang terdapat di KPP Pratama Gianyar cenderung mengalami penurunan. Hal ini mengindikasikan bahwa tingkat kepatuhan pajak WPOP UMKM di KPP Pratama Gianyar masih jauh dibawah target kepatuhan pajak nasional yang telah ditetapkan Direktorat Jendral Pajak berdasarkan atas Surat Edaran Nomor SE-07/PJ/2016 yaitu 70 persen.

Menurut Novia (2019) Tarif pajak merupakan salah satu faktor yang mempengaruhi kepatuhan pajak. Adanya revisi peraturan PPh final UMKM terbaru yang disahkan dengan Peraturan Pemerintah nomor 23 tahun 2018 yaitu penurunan tarif pajak final UMKM dari 1 persen menjadi 0,5 persen diharapkan dapat meningkatkan kepatuhan wajib pajak untuk melaporkan dan membayar pajak terutangnya.

Menurut Burhan (2015), kurangnya sosialisasi perpajakan untuk masyarakat berakibat pada rendahnya pengetahuan para wajib pajak yang akan membuat kepatuhan untuk menjalankan kewajiban perpajakan semakin menurun. Untuk lebih meningkatkan pemahaman wajib pajak mengenai peraturan pajak yang baru berlaku, perlu diadakan sosialisasi yang teratur oleh pemerintah dalam hal ini DJP dan dibantu oleh Kantor Pelayanan Pajak di masing-masing daerah.

Sanksi pajak juga merupakan salah satu variabel yang dapat mempengaruhi kepatuhan wajib pajak dalam melaksanakan kewajibannya. Pemerintah dalam hal ini Direktorat Jendral Pajak harus tegas dalam menerapkan sanksi kepada wajib pajak yang melanggar, sehingga akan menimbulkan efek jera kepada pelanggar pajak. Penelitian yang dilakukan oleh Aditya Pranata (2015), Sari (2018) dan Eben Ezer (2017) menghasilkan bahwa sanksi pajak berpengaruh positif terhadap kepatuhan pajak.

Pemeriksaan pajak sangat diperlukan sebagai bentuk pengawasan terhadap wajib pajak agar wajib pajak tetap berada dalam peraturan pajak yang berlaku. Pada penelitian yang dilakukan Palil ( 2010 ) ditemukan hasil bahwa pemeriksaan pajak dapat mendorong wajib pajak untuk lebih patuh dalam mengisi dan melaporkan SPT Tahunan Pajak Penghasilan.

Berdasarkan uraian latar belakang di atas maka penelitian ini akan dilakukan dengan judul pengaruh tarif pajak, sosialisasi pajak, sanksi pajak dan pemeriksaan pajak terhadap tingkat kepatuhan pelaporan wajib pajak orang pribadi usaha mikro, kecil dan menengah di Kantor Pelayanan Pajak Pratama Gianyar.

\section{KAJIAN TEORI}

1. Theory of Planned Behaviour

Theory of Planned Behavior dikembangkan oleh Icek Ajzen (1988). Teori ini merupakan pengembangan dari Theory of Reasones Action (TRA) yang dimana menjelaskan bahwa individu berperilaku atas dasar niat atau keinginan dari individu itu sendiri untuk melakukannya. Di dalam TPB ditambahkan sebuah variabel yang sebelumnya tidak terdapat pada TRA yaitu variabel Kontrol Keperilakuan yang Dipersepsikan (perceived behavioral control). Theory of Planned Behavior menunjukkan bahwa tindakan manusia diarahkan oleh 
tiga macam kepercayaan/keyakinan yaitu Behavioral Beliefs, Normatif Beliefs, dan Control Beliefs (Jogiyanto Hartono, 2010). Normative Beliefs berkaitan dengan tarif pajak dan sosialisasi pajak, yaitu ketika individu melakukan sesuatu, individu cenderung mengharapkan hal normatif dari orang tersebut, dengan adanya penyuluhan atau sosialisasi akan memberikan motivasi terhadap wajib pajak agar taat pajak. Control Beliefs berkaitan dengan sanksi pajak serta pemeriksaan wajib pajak hal ini dilakukan agar wajib pajak mematuhi aturan perpajakan.

2. Peraturan Pemerintah Nomor 23 Tahun 2018

Peraturan Pemerintah Nomor 23 Tahun 2018 adalah peraturan mengenai Pajak Penghasilan atas penghasilan dari usaha yang diterima atau diperoleh wajib pajak yang memiliki peredaran bruto tertentu dalam satu tahun pajak. Peraturan ini diberlakukan secara efektif pada tanggal 1 Juli 2018. Adapun tujuan dari perubahan peraturan ini adalah menurunkan tarif pajak yang sebelumnya adalah 1 persen menjadi 0,5 persen.

3. Usaha Mikro, Kecil dan Menengah

Usaha Mikro, Kecil dan Menengah (UMKM) memiliki peranan yang berpengaruh untuk pembangunan ekonomi nasional. Selain itu UMKM juga membantu meningkatkan penyerapan tenaga kerja dan UMKM juga berperan dalam mendistribusikan hasil pembangunan.

Tabel 2.1

Kriteria Usaha Mikro, Kecil, Menengah, Dan Besar

\begin{tabular}{|c|c|c|}
\hline \multirow{2}{*}{ Ukuran Usaha } & \multicolumn{2}{|l|}{ Kriteria } \\
\hline & Aset & Omset \\
\hline Usaha Mikro & Maksimal Rp50 juta & Maksimal Rp300 juta \\
\hline Usaha Kecil & $>$ Rp50 juta - Rp500 juta & $\begin{array}{l}>\text { Rp300 juta }-\mathrm{Rp} 2,5 \\
\text { miliar }\end{array}$ \\
\hline Usaha Menengah & $>$ Rp500 juta - Rp10 miliar & $\begin{array}{l}>\mathrm{Rp} 2,5 \text { miliar }-\mathrm{Rp} 50 \\
\text { miliar }\end{array}$ \\
\hline Usaha Besar & $>$ Rp10 miliar & > Rp50 miliar \\
\hline
\end{tabular}

Sumber : Kementrian Koperasi dan Usaha Kecil Menengah, 2020

4. Kepatuhan Pajak

Menurut Keputusan Menteri Keuangan No.544/KMK.04/2000 menyatakan bahwa kepatuhan perpajakan adalah tindakan Wajib Pajak dalam pemenuhan kewajiban perpajakannya sesuai dengan ketentuan peraturan perundang-undangan dan peraturan pelaksanaan perpajakan yang berlaku dalam suatu Negara. Adapun kreteria wajib pajak yang patuh yang diatur dalam Keputusan Menteri Keuangan No.544/KMK.04/2000 adalah sebagai berikut .

a. Tepat waktu dalam menyampaikan SPT untuk semua jenis pajak dalam dua tahun terakhir.

b. Tidak mempunyai tunggakan atas pajak untuk semua jenis pajak, kecuali telah memeroleh izin untuk mengangsur atau menunda pembayaran pajak.

c. Tidak pernah dijatuhi hukuman dikarenakan melakukan tindak pidana di bidang perpajakan dalam jangka waktu 10 tahun terakhir.

d. Dalam dua tahun terakhir menyelenggarakan pembukuan dan dalam hal terhadap wajib pajak pernah dilakukan pemeriksaan, koreksi pada pemeriksaan yang terakhir untuk tiap-tiap jenis pajak terutang paling banyak 5 persen.

e. Wajib pajak yang laporan keuangannya untuk dua tahun terakhir diaudit oleh akuntan publik dengan pendapat wajar tanpa pengecualian atau pendapat pengecualian sepanjang tidak memengaruhi laba rugi fiskal. 


\section{Tarif Pajak}

Menurut Pris (2010), pemberlakuan tarif pajak mempengaruhi wajib pajak dalam membayar pajaknya. Pembebanan pajak yang relatif rendah membuat masyarakat tidak terlalu keberatan untuk memenuhi kewajiban pajaknya. Meskipun masih ingin menghindar dari pajak, wajib pajak tidak akan terlalu membangkang terhadap aturan-aturan perpajakan. Sehingga dapat dipahami semakin adil tarif pajak yang ditetapkan maka akan semakin tinggi tingkat kepatuhan wajib pajak dalam membayar pajak. Asas keadilan dalam perpajakan adalah penyetaraan perbuatan sesuai dengan keadaan perpajakan wajib pajak yang sebenarnya (Mustofa dkk, 2013 : 03). Syarat keadilan sesuai dengan keadilan hukum, yakni mencapai keadilan, undang-undang pelaksanaan pemungutan harus adil. Adil didalam perundangundangan dapat diartikan mengenakan pajak secara umum dan merata, serta disesuaikan dengan kemampuan masing-masing. Sedangkan adil dalam pelaksanaan dapat diartikan dapat memberikan hak bagi wajib pajak untuk megajukan keberatan, penundaan dalam pembayaran dan mengajukan banding kepada majelis pertimbangan pajak (Endrianto, 2015: 304).

6. Sosialisasi Pajak

Sosialisasi merupakan suatu proses untuk mempelajari norma maupun nilai yang berlaku dimasyarakat, sehingga individu dapat menyesuaikan diri dengan aturan yang ada dan dapat diterima sebagai anggota masyarakat. Adapun kaitannya dengan perpajakan, adanya sosialisasi agar masyarakat dapat mengetahui mengenai peraturan perpajakan yang berlaku umum. Dirjen Pajak mengeluarkan Surat Edaran Direktur Jendral Pajak Nomor SE22/PJ/2007 untuk mengatur mengenai keseragaman penyampaian sosialisasi perpajakan bagi masyarakat. Penyampaian informasi perpajakan dapat dilakukan dengan mengadakan seminar, dikusi maupun acara sejenisnya tentunya dengan menggunakan bahasa yang sesederhana mungkin dan mudah dimengerti, sehingga informasi tersebut akan dengan mudah diterima.

7. Sanksi Pajak

Sanksi merupakan hukuman bagi seseorang yang melanggar aturan yang telah disepakati secara bersama. Sanksi pajak merupakan sanksi yang diberikan kepada wajib pajak yang tidak taat atau melanggar aturan pajak yang telah ditetapkan seperti ketika wajib pajak terlambat membayar pajak atau membuat keterangan yang kurang tepat pada SPT. Sanksi pajak dijelaskan dalam Undang - Undang Nomor 28 Tahun 2007 perubahan ketiga atas Undang - Undang Nomor 6 Tahun 1983 Tentang Ketentuan Umum dan Tata Cara Perpajakan, dan Undang - Undang Nomor 12 Tahun 1994 Perubahan Atas Undang Undang Nomor 12 Tahun 1985 Tentang Pajak Bumi dan Bangunan. Berdasarkan peraturan tersebut, sanksi pajak dibedakan menjadi dua yaitu Sanksi Administratif dan Sanksi Pidana.

8. Pemeriksaan Pajak

Pemeriksaan pajak merupakan serangkaian kegiatan untuk mengumpulkan dan mengolah data atau bukti yang didapatkan dan dilaksanakan secara objektif dan profesional berdasarkan atas standar pemeriksaan untuk menguji kepatuhan dalam melaksanakan kewajiban perpajakan dan/atau untuk tujuan lain dalam rangka melaksanakan ketentuan peraturan perunang-undangan perpajakan (UU No.28 Tahun 2007). Menurut OECD (Organization fo Economic Cooperation and Development) pemeriksaan pajak adalah pemeriksaan kepada wajib pajak dengan tujuan untuk menilai apakah wajib pajak telah dengan benar melaporkan kewajiban pajak dan memenuhi kewajiban lainnya. Direktur Jendral Pajak memiliki wewenang dalam melakukan pemeriksaan untuk menguji kepatuhan wajib pajak (UU No. 28 Tahun 2007).

\section{Hipotesis}


1. Pengaruh Tarif Pajak terhadap Kepatuhan Pajak Wajib Pajak Orang Pribadi UMKM

Berdasarkan Theory of Planned Behavior (Ajen,1988) menjelaskan bahwa tidak semua perilaku dilakukan di bawah kendali individu ataupun kelompok, sehingga konsep kontrol keperilakuan yang dipersepsikan ditambahkan untuk mengatasi perilaku yang tidak dalam kendali individu maupun kelompok tersebut. Menurut Pris (2010), pemberlakuan tarif pajak mempengaruhi wajib pajak dalam membayar pajaknya. Pembebanan pajak yang rendah membuat masyarakat tidak terlalu merasa keberatan untuk memenuhi kewajibannya untuk membayarkan pajak. Tarif pajak sebelumnya yaitu tarif final 1 persen ada yang menganggap bahwa tarif pajak tersebut lebih tinggi dari pada tarif pajak sebelumnya, karena tarif pajak sebesar 1 persen dihitung dari omset tanpa melihat pemilik UMKM mengalami kerugian atau laba dan tidak dikurangi dengan penghasilan tidak kena pajak (Yusro dan Kiswanto, 2014 : 432). Pemerintah lalu mengeluarkan peraturan terbaru mengenai tarif final UMKM dan besarnya tarif final UMKM saat ini sudah turun menjadi 0,5 persen dengan harapan mampu memotivasi wajib pajak untuk semakin mematuhi kewajiban perpajakannya. Maka dari itu berdasarkan uraian di atas dapat dirumuskan hipotesis sebagai berikut:

$\mathrm{H}_{1}$ : Tarif Pajak berpengaruh positif terhadap Kepatuhan Wajib Pajak Orang Pribadi UMKM

2. Pengaruh Sosialisasi Pajak terhadap Kepatuhan Pajak Wajib Pajak Orang Pribadi UMKM

Berdasarkan Theory of Planned Behavior (Ajen,1988) Sosialisasi perpajakan merupakan salah satu faktor yang dapat memengaruhi tingkat kepatuhan wajib pajak yaitu normative beliefs. Meningkatnya tingkat pengetahuan pajak dapat mempengaruhi tingkat kepatuhan wajib pajak (Manual \& Xin, 2016). Berdasarkan penelitian yang dilakukan oleh Megantara (2017) sosialisasi pajak berpengaruh positf terhadap tingkat kepatuhan wajib pajak. Maka dari itu berdasarkan uraian di atas dapat dirumuskan hipotesis sebagai berikut :

$\mathrm{H}_{2}$ : Sosialisasi pajak berpengaruh positif terhadap Kepatuhan Wajib Pajak Orang Pribadi UMKM

3. Pengaruh Sanksi Pajak terhadap Kepatuhan Pajak Wajib Pajak Orang Pribadi UMKM

Sanksi pajak merupakan salah satu faktor eksternal yang dapat memengaruhi tingkat kepatuhan wajib pajak. Hal ini juga sejalan dengan Theory of Planned Behavior (Ajen,1988) yaitu sanksi pajak menjadi control beliefs bagi wajib pajak, dimana wajib pajak akan diberikan sanksi jika tidak melaksanakan kewajiban membayar pajak sesuai dengan aturan yang berlaku. Pada penelitian Fuadi dan Yeni (2013) mendapatkan hasil bahwa sanksi pajak berpengaruh positif terhadap kepatuhan pajak UMKM. Maka dari itu berdasarkan uraian di atas, dapat dirumuskan hipotesis sebagai berikut :

$\mathrm{H}_{3}$ : $\quad$ Sanksi pajak berpengaruh positif terhadap Kepatuhan Wajib Pajak Orang Pribadi UMKM

4. Pengaruh Pemeriksaan pajak terhadap Kepatuhan Wajib Pajak Orang Pribadi UMKM

Pemeriksaan merupakan suatu kegiatan menghimpun dan mengolah data, bukti maupun keterangan pendukung yang dilaksanakan secara objektif dan profesional berdasarkan standar yang telah ditetapkan. Berdasarkan theory of planned behavior (Ajen,1988) pemeriksaan pajak terkait dengan control beliefs, wajib pajak akan menumbuhkan persepsi bahwa dengan meningkatknya frekuensi pemeriksaan pajak, maka kemungkinan akan mendapatkan bukti mengenai pelaporan pajak yang tidak sesuai peraturan semakin tinggi. Penelitian yang dilakukan oleh Mandagi (2014) ditemukan hasil bahwa pemeriksaan pajak berpengaruh positif terhadap tingkat kepatuhan wajib pajak. Berdasarkan uraian tersebut, maka didapatkan rumusan hipotesis sebagai berikut :

$\mathrm{H}_{4}$ : Pemeriksaan pajak berpengaruh positif terhadap Kepatuhan Wajib Pajak Orang Pribadi UMKM 


\section{METODE PENELITIAN}

Jenis penelitian ini adalah penelitian kuantitatif yang berbentuk asosiatif dengan tipe kausalitas. Penelitian asosiatif merupakan penelitian yang memiliki tujuan untuk mengetahui hubungan antara dua variabel atau lebih. Penelitian asosiatif dengan tipe kausalitas adalah penelitian yang menjelaskan pengaruh variabel independen terhadap variabel dependen (Sugiyono, 2017). Pada penelitian ini variabel dependennya adalah kepatuhan wajib pajak sedangkan variabel independennya adalah tarif pajak, sosialisasi pajak, sanksi pajak, dan pemeriksaaan pajak. Metode pengumpulan data yang digunakan dalam penelitian ini adalah metode accidental sampling. Populasi pada penelitian ini adalah Wajib Pajak Orang Pribadi UMKM yang terdaftar pada Kantor Pelayanan Pajak Pratama Gianyar yang memiliki peredaran bruto kurang atau sama dengan Rp4,8 miliar pertahun yaitu sebanyak 18.102 orang. Jumlah sampel Wajib pajak orang pribadi UMKM dalam penelitian ini dihitung menggunakan rumus Slovin dan didapat sebanyak 100 sampel. Analisis yang digunakan dalam penelitian ini adalah analisis regresi berganda dengan menggunakan bantuan software SPSS 18.0 for windows Persamaan regresi yang dirumuskan berdasarkan hipotesis yang dikembangkan adalah sebagai berikut.

$$
\begin{aligned}
& Y=\alpha+\beta_{1} X_{1}+\beta_{2} X_{2}+\beta_{3} X_{3}+\beta_{4} X_{4}+\varepsilon \\
& \text { Keterangan : } \\
& Y \quad=\text { Perilaku kepatuhan pajak UMKM } \\
& \alpha \quad=\text { Konstanta } \\
& \beta \quad=\text { Koefisien regresi variabel } X_{1-} X_{4} \\
& X_{1} \quad=\text { Tarif Pajak } \\
& X_{2}=\text { Sosialisasi Pajak } \\
& X_{3} \quad=\text { Sanksi Pajak } \\
& X_{4}=\text { Pemeriksaan Pajak } \\
& \varepsilon \quad=\text { Error }
\end{aligned}
$$

\begin{tabular}{|c|c|c|c|c|c|}
\hline & $\begin{array}{l}\text { Tarif } \\
\text { Pajak }\end{array}$ & $\begin{array}{l}\text { Sosialisasi } \\
\text { Pajak }\end{array}$ & $\begin{array}{l}\text { Sanksi } \\
\text { Pajak }\end{array}$ & $\begin{array}{l}\text { Pemeriksaan } \\
\text { WP }\end{array}$ & $\begin{array}{l}\text { Kepatuhan } \\
\text { Wajib } \\
\text { Pajak }\end{array}$ \\
\hline $\mathrm{N}$ & 100 & 100 & 100 & 100 & 100 \\
\hline Normal Mean & 16.9700 & 13.7600 & 17.2400 & 33.9800 & 24.4700 \\
\hline Parameters $^{\mathrm{a}, \mathrm{b}} \quad$ Std. & 1.83377 & 1.49828 & 1.65828 & 3.29671 & 2.52044 \\
\hline Most Extreme Absolute & .172 & .160 & .147 & .140 & .144 \\
\hline Differences Positive & 172 & .160 & .143 & .126 & .144 \\
\hline Negative & -.126 & -.134 & -.147 & -.140 & -.122 \\
\hline Kolmogorov-Smirnov Z & 1.716 & 1.599 & 1.466 & 1.402 & 1.440 \\
\hline Asymp. Sig. (2-tailed) & .055 & .120 & .271 & 393 & .317 \\
\hline
\end{tabular}

\section{HASIL DAN PEMBAHASAN}

Uji Asumsi Klasik

1. Uji Normalitas

\section{TABEL 4.5}

\section{HASIL UJI NORMALITAS}

One-Sample Kolmogorov-Smirnov Test 
Berdasarkan hasil analisis uji normalitas pada masing-masing variabel memiliki nilai signifikansi uji Kolmogorov-Smirnov lebih dari 0,05 maka dapat disimpulkan bahwa seluruh variabel pada model persamaan regresi tersebut berdistribusi normal.

2. Uji Multikolinieritas

TABEL 4.6

HASIL UJI MULTIKOLENIARITAS

\begin{tabular}{|llll|}
\hline Variabel & Tolerance & VIF & Keterangan \\
\hline Tarif pajak $\left(\mathrm{X}_{1}\right)$ & 0,579 & 1,726 & Bebas multikolinieritas \\
\hline Sosialisasi pajak $\left(\mathrm{X}_{2}\right)$ & 0,630 & 1,587 & Bebas multikolinieritas \\
\hline Sanksi pajak $\left(\mathrm{X}_{3}\right)$ & 0,919 & 1,088 & Bebas multikolinieritas \\
\hline Pemeriksaan pajak $\left(\mathrm{X}_{4}\right)$ & 0,716 & 1,397 & Bebas multikolinieritas \\
\hline
\end{tabular}

Hasil pada tabel 4.6 menunjukkan bahwa nilai tolerance untuk setiap variabel lebih besar dari $10 \%$ dan nilai VIF lebih kecil dari 10 yang berarti model persamaan regresi bebas dari multikolinearitas.

3. Uji Heterokedastisitas

TABEL 4.7

HASIL UJI HETEROSKEDASTISITAS

\begin{tabular}{|llll|}
\hline No & Variabel Bebas & Signifikansi & Keterangan \\
\hline 1 & Tarif pajak & 0,653 & Bebas heteroskedastisitas \\
\hline 2 & Sosialisasi pajak & 0,055 & Bebas heteroskedastisitas \\
\hline 3 & Sanksi pajak & 0,155 & Bebas heteroskedastisitas \\
\hline 4 & Pemeriksaan pajak & 0,964 & Bebas heteroskedastisitas \\
\hline
\end{tabular}

Pada Tabel 4.7 dapat dilihat bahwa nilai Signifikansi dari variabel tarif pajak sebesar 0,653 , sosialisasi pajak sebesar 0,055 , sanksi pajak sebesar 0,155 , dan pemeriksaan pajak sebesar 0,964 . Nilai tersebut lebih besar dari 0,05 yang berarti tidak terdapat pengaruh antara variabel bebas terhadap absolute residual. Dengan demikian, model yang dibuat tidak mengandung gejala heteroskedastisitas.

Analisis Regresi Linier Berganda

Tabel 4.8

Hasil Analisis Regresi Linier Berganda

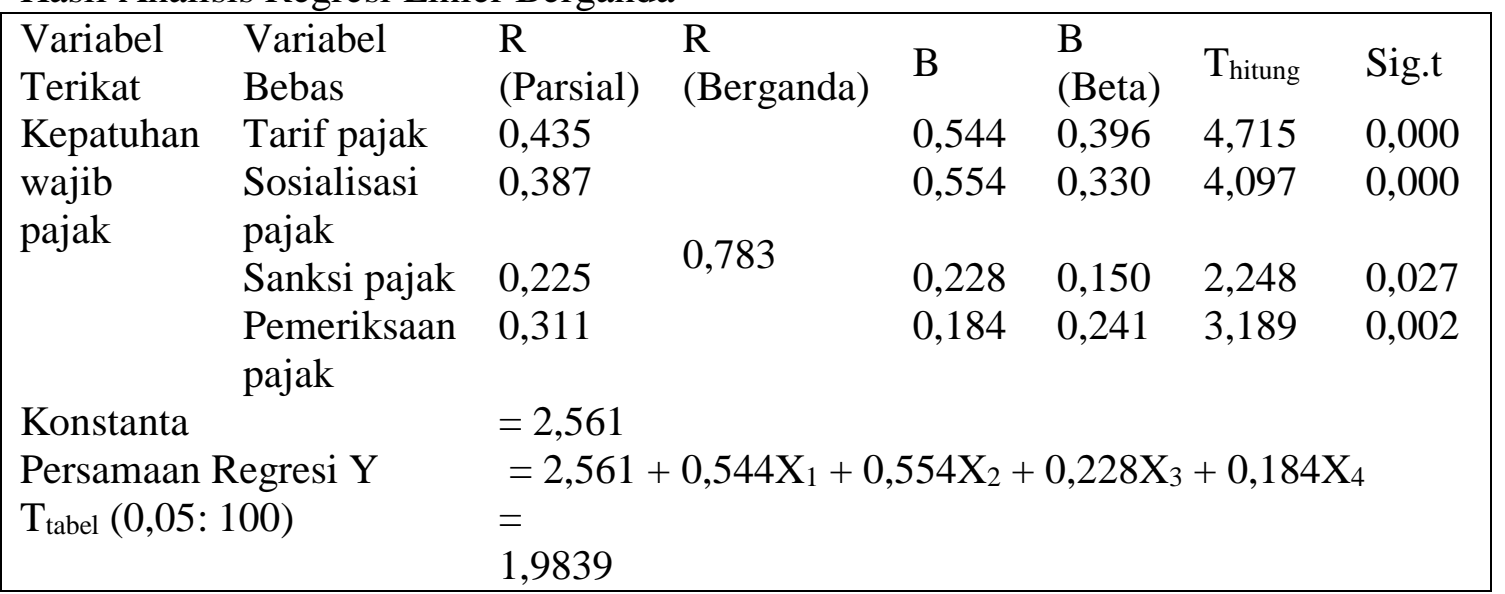

Persamaan regresi linier berganda yaitu : 
$Y=\alpha+\beta_{1} X_{1}+\beta_{2} X_{2}+\beta_{3} X_{3}+\beta_{4} X_{4}+\varepsilon$

$\mathrm{Y}=22,561+0,544 \mathrm{X}_{1}+0,554 \mathrm{X}_{2}+0,228 \mathrm{X}_{3}+0,184 \mathrm{X}_{4}$

Uji Koefisien Determinasi $\left(\mathrm{R}^{2}\right)$

Tabel 4.9

Hasil Uji Koefisien Determinasi

\begin{tabular}{|clllll|}
\hline Model & & Adjusted R Square & $\begin{array}{l}\text { Std, Error of the } \\
\text { Estimate }\end{array}$ & \\
\hline 1 & $0,783^{\mathrm{a}}$ & 0,613 & 0,596 & 1,60144 & \\
\hline
\end{tabular}

Hasil uji R Square pada Tabel 4.9 adalah sebesar 0,613 mempunyai arti bahwa sebesar 61,3\% variasi Kepatuhan Wajib Pajak Orang Pribadi UMKM di KPP Pratama Gianyar dipengaruhi oleh variasi tarif pajak $\left(\mathrm{X}_{1}\right)$, sosialisasi pajak $\left(\mathrm{X}_{2}\right)$, sanksi pajak $\left(\mathrm{X}_{3}\right)$, dan pemeriksaan pajak $\left(\mathrm{X}_{4}\right)$, sedangkan sisanya sebesar $38,7 \%$ djelaskan oleh faktor lain yang tidak dimasukkan ke dalam model.

Hasil Uji Kelayakan Model (Uji-F)

TABEL 4.10

HASIL UJI F

\begin{tabular}{|c|c|c|c|c|c|c|}
\hline \multirow{2}{*}{\multicolumn{2}{|c|}{ Model }} & Sum & $f$ & & & \\
\hline & & Squares & Df & Mean Square & & Sig. \\
\hline \multirow[t]{3}{*}{1} & Regression & 385.272 & 4 & 96.318 & 37.557 & $.000^{\mathrm{a}}$ \\
\hline & Residual & 243.638 & 95 & 2.565 & & \\
\hline & Total & 628.910 & 99 & & & \\
\hline
\end{tabular}

Sumber : Lampiran 8

Hasil pengolahan data pada Tabel 4.10 menunjukkan nilai $F_{\text {hitung }}>F_{\text {tabel }}, 37,557>2,46$ dengan nilai sig. $0,000<0,05$, maka dapat disimpulkan bahwa model regresi layak digunakan.

Hasil Uji Statistik t (Uji-t)

TABEL 4.11

HASIL UJI T

\begin{tabular}{|c|c|c|c|c|c|c|c|c|}
\hline \multirow[t]{2}{*}{ Model } & \multicolumn{2}{|c|}{$\begin{array}{l}\text { Unstandardized } \\
\text { Coefficients }\end{array}$} & \multicolumn{2}{|c|}{$\begin{array}{l}\text { Standardized } \\
\text { Coefficients }\end{array}$} & \multirow[b]{2}{*}{ Sig. } & \multicolumn{3}{|c|}{ Correlations } \\
\hline & B & Std. E & r Beta & $\mathrm{t}$ & & $\begin{array}{l}\text { Zero- } \\
\text { order }\end{array}$ & Partial & Part \\
\hline (Constant) & 2.561 & 2.770 & & .925 & .358 & & & \\
\hline Tarif Pajak & .544 & .115 & .396 & 4.715 & .000 & .659 & .435 & .301 \\
\hline $\begin{array}{l}\text { Sosialisasi } \\
\text { Pajak }\end{array}$ & .554 & .135 & .330 & 4.097 & .000 & .645 & .387 & .262 \\
\hline Sanksi Pajak & .228 & .101 & .150 & 2.248 & .027 & .007 & .225 & .144 \\
\hline $\begin{array}{l}\text { Pemeriksaan } \\
\text { WP }\end{array}$ & .184 & .058 & .241 & 3.189 & .002 & .575 & .311 & .204 \\
\hline
\end{tabular}

a. Dependent Variable: Kepatuhan Wajib Pajak 
1.Pengaruh Tarif pajak Terhadap Kepatuhan wajib pajak

Berdasarkan hasil analisis pengaruh tarif pajak terhadap kepatuhan wajib pajak diperoleh nilai signifikasi sebesar 0,000 dengan nilai thitung sebesar 4,715 lebih besar dari nilai $t_{\text {tabel }}$ sebesar 1,9839 . Oleh karena nilai $t_{h i t u n g}>t_{\text {tabel }}(4,715>1,9839)$ dan nilai signifikansi $0,000<$ 0,05 mengindikasikan bahwa tarif pajak secara parsial berpengaruh positif dan signifikan terhadap tingkat kepatuhan pajak Wajib Pajak Orang Pribadi UMKM di KPP Pratama Gianyar.

2. Pengaruh Sosialisasi pajak Terhadap Kepatuhan wajib pajak.

Berdasarkan hasil analisis pengaruh sosialisasi pajak terhadap kepatuhan wajib pajak diperoleh nilai signifikansi sebesar 0,000 dengan nilai $t_{\text {hitung }}$ sebesar 4,097 lebih besar dari nilai $t_{\text {tabel }}$ sebesar 1,9839. Oleh karena nilai $t_{\text {hitung }}>t_{\text {tabel }}(4,097>1,9839)$ dan nilai signifikansi $0,000<0,05$ mengindikasikan bahwa sosialisasi pajak secara parsial berpengaruh positif dan signifikan terhadap tingkat kepatuhan pajak Wajib Pajak Orang Pribadi UMKM di KPP Pratama Gianyar.

3. Pengaruh Sanksi pajak Terhadap Kepatuhan wajib pajak

Berdasarkan hasil analisis pengaruh sanksi pajak terhadap kepatuhan wajib pajak diperoleh nilai signifikansi sebesar 0,027 dengan nilai $t_{\text {hitung }}$ sebesar 2,248 lebih besar dari nilai $t_{\text {tabel }}$ sebesar 1,9839 . Oleh karena nilai $t_{\text {hitung }}>t_{\text {tabel }}(2,248>1,9839)$ dan nilai signifikansi $0,027<$ 0,05 mengindikasikan bahwa sanksi pajak secara parsial berpengaruh positif dan signifikan terhadap tingkat kepatuhan pajak Wajib Pajak Orang Pribadi UMKM di KPP Pratama Gianyar.

4. Pengaruh Pemeriksaan pajak Terhadap Kepatuhan wajib pajak

Berdasarkan hasil analisis pengaruh pemeriksaan pajak terhadap kepatuhan wajib pajak

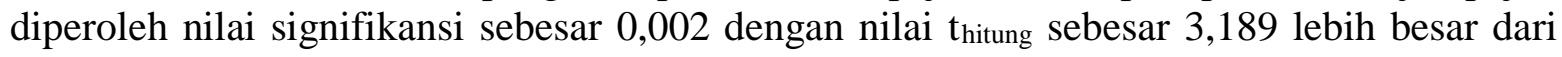
nilai $t_{\text {tabel }}$ sebesar 1,9839 . Nilai $t_{\text {hitung }}>t_{\text {tabel }}(3,189>1,9839)$ dan nilai signifikansi $0,002<0,05$ mengindikasikan bahwa pemeriksaan pajak secara parsial berpengaruh positif dan signifikan terhadap tingkat kepatuhan pajak Wajib Pajak Orang Pribadi UMKM di KPP Pratama Gianyar.

Pembahasan Hasil Penelitian

1.Pengaruh Tarif pajak Terhadap Kepatuhan wajib pajak

Hasil analisis menunjukkan bahwa tarif pajak berpengaruh positif dan signifikan terhadap kepatuhan wajib pajak. Hal ini berarti bahwa semakin adil tarif pajak yang diberikan pada Wajib Pajak Orang Pribadi UMKM maka akan semakin meningkatkan tingkat kepatuhan pajak pada Wajib Pajak Orang Pribadi UMKM di KPP Pratama Gianyar. Begitu pula sebaliknya, semakin tidak adil tarif pajak yang diberikan maka akan tingkat kepatuhan pajak Wajib Pajak Orang Pribadi UMKM di KPP Pratama Gianyar tersebut akan semakin berkurang. Penelitian ini sesuai dengan Theory of Planned Behavior dan hasil ini mendukung temuan penelitian Ananda (2015) yang menyebutkan bahwa tarif pajak berpengaruh terhadap tingkat kepatuhan wajib pajak.

2. Pengaruh Sosialisasi pajak Terhadap Kepatuhan wajib pajak

Hasil analisis menunjukkan bahwa sosialisasi pajak berpengaruh positif dan signifikan terhadap kepatuhan wajib pajak. Hal ini berarti bahwa semakin efektif pelaksanaan sosialisasi pajak yang diberikan KPP Pratama Gianyar pada Wajib Pajak Orang Pribadi UMKM maka akan semakin meningkatkan tingkat kepatuhan pajak Wajib Pajak Orang Pribadi UMKM. Begitu pula sebaliknya, semakin tidak efektif pelaksanaan sosialisasi pajak yang diberikan KPP Pratama Gianyar pada Wajib Pajak Orang Pribadi UMKM maka tingkat kepatuhan pajak Wajib Pajak Orang Pribadi UMKM tersebut akan semakin 
menurun. Hasil penelitian ini mendukung hasil penelitian Megantara (2017) yang menyatakan bahwa sosialisasi pajak berpengaruh positf terhadap tingkat kepatuhan wajib pajak.

\section{Pengaruh Sanksi pajak Terhadap Kepatuhan wajib pajak}

Hasil analisis menunjukkan bahwa sanksi pajak berpengaruh positif dan signifikan terhadap kepatuhan wajib pajak. Hasil penelitian menunjukkan bahwa semakin berat sanksi perpajakan yang diberikan pada WPOP UMKM yang melanggar maka akan menyebabkan wajib pajak semakin patuh, begitu sebaliknya semakin kurang tegas sanksi perpajakan yang diberikan maka wajib pajak akan semakin tidak patuh. Hal ini juga sejalan dengan Theory of Planned Behavior yaitu sanksi pajak menjadi control beliefs bagi wajib pajak, dimana wajib pajak akan diberikan sanksi jika tidak melaksanakan kewajiban membayar pajak sesuai dengan aturan yang berlaku.

4.Pengaruh Pemeriksaan pajak Terhadap Kepatuhan wajib pajak

Hasil analisis menunjukkan bahwa pemeriksaan pajak berpengaruh positif dan signifikan terhadap kepatuhan wajib pajak. Hal ini berarti bahwa semakin sering pemeriksaan pajak dilakukan pada WPOP UMKM maka akan mendorong tingkat kepatuhan pajak Wajib Pajak Orang Pribadi UMKM yang semakin meningkat. Begitu pula sebaliknya, semakin jarang pemeriksaan pajak dilakukan pada WPOP UMKM, maka semakin menurunkan tingkat kepatuhan pajak Wajib Pajak Orang Pribadi UMKM tersebut. Penelitian ini sesuai dengan theory of planned behavior terkait dengan control beliefs, menurut pendapat Gupta (2009) yakni semakin tinggi tingkat kemungkinan pemeriksaan maka akan semakin menuruh tingkat penggelapan pajak.

\section{SIMPULAN DAN SARAN}

\section{Simpulan}

Berdasarkan hasil penelitian dan pembahasan pada bab sebelumnya maka dapat ditarik simpulan sebagai berikut:

1. Tarif pajak berpengaruh positif dan signifikan terhadap Kepatuhan wajib pajak. Hal ini berarti bahwa semakin adil tarif pajak yang diberikan pada Wajib Pajak Orang Pribadi UMKM maka akan semakin meningkatkan tingkat kepatuhan pajak pada Wajib Pajak Orang Pribadi UMKM di KPP Pratama Gianyar.

2. Sosialisasi pajak berpengaruh positif dan signifikan terhadap kepatuhan wajib pajak. Hal ini berarti bahwa semakin efektif pelaksanaan sosialisasi pajak yang diberikan KPP Pratama Gianyar pada Wajib Pajak Orang Pribadi UMKM maka akan semakin meningkatkan tingkat kepatuhan pajak Wajib Pajak Orang Pribadi UMKM.

3. Sanksi pajak berpengaruh positif dan signifikan terhadap kepatuhan wajib pajak. Hal ini berarti semakin berat sanksi perpajakan yang diberikan pada WPOP UMKM yang melanggar maka akan menyebabkan wajib pajak semakin patuh

4. Pemeriksaan pajak berpengaruh positif dan signifikan terhadap kepatuhan wajib pajak. Hal ini berarti bahwa semakin sering pemeriksaan pajak dilakukan pada WPOP UMKM maka akan mendorong tingkat kepatuhan pajak Wajib Pajak Orang Pribadi UMKM yang semakin meningkat.

Saran

Saran yang dapat diberikan berdasarkan hasil penelitian adalah sebagai berikut:

1. Penelitian ini terbatas dilakukan di KPP pratama Gianyar, sehingga diisarankan bagi penelitian selanjutnya untuk melakukan penelitian pada beberapa KPP pratama yang berada di Provinsi Bali untuk memperoleh hasil penelitian yang lebih akurat, lebih 
meyakinkan dan dapat membandingkan hasil dari penelitian tersebut.

2. Banyaknya pernyataan setiap variabel dalam kuesioner membuat wajib pajak tidak tertarik dan enggan untuk membaca. Disarankan penelitian selanjutnya agar mengurangi atau meringkas pernyataan sehingga jumlahnya sedikit namun memiliki makna luas dan mencangkup semuanya.

3. Penelitian ini menggunakan empat variabel independen yang mempengaruhi kepatuhan wajib pajak sehingga disarankan penelitian selanjutnya untuk mengamati faktor-faktor lain yang dapat mempengaruhi kepatuhan wajib pajak seperti variabel kesadaran wajib pajak, pelayanan fiskus, maupun variabel lainnya.

\section{REFERENSI}

Aditya Pranata, Putu.2015. Pengaruh Sanksi Perpajakan, Kualitas Pelayanan dan Kewajiban Moral Pada Kepatuhan Wajib Pajak. E-Jurnal Akuntansi Universitas Udayana, 10(2), 456-473.

Agustiantono, Dwi.2012. Analisis Faktor-Faktor Yang Memengaruhi Kepatuhan Wajib Pajak Orang Pribadi: Aplikasi TPB (Studi Empiris WPOP di Kabupaten Pati). Skripsi. Semarang: Fakultas Ekonomi dan Bisnis, Universitas Diponogoro.

Ajzen, Icek. 1988. From Intentions to Actions: Attitudes, Personality, \& Behavior. Chicago: Dorsey Press.

.1991. The Theory Of Planned Behavior. Academic Press. Inc.

.2006. Constructing a TpB Questionnaire: Conceptual and Methodological

Considerations. Occasional paper. Diunduh dari website: Http://people.umass.edu/aizen/. 1 Oktober 2018

Ananda, Pasca. 2015. Pengaruh Sosialisasi Perpajakan, Tarif Pajak, Dan Pemahaman Perpajakan Terhadap Kepatuhan Wajib Pajak. Jurnal Perpajakan, 6 (2), hal.1-9.

Atmadja, A. T., Saputra, K. A. K., Tama, G. M., \& Paranoan, S. (2021). Influence of Human Resources, Financial Attitudes, and Coordination on Cooperative Financial Management. The Journal of Asian Finance, Economics, and Business, 8(2), 563-570.

Cahyani, Luh Putu Gita. 2019. Pengaruh Tarif Pajak, Pemahaman Perpajakan, dan Sanksi Perpajakan Terhadap Kepatuhan Wajib Pajak UMKM. E-Jurnal Akuntansi Universitas Udayana, 26(3), 1885-1911. https://doi.org/10.2484/EJA.2019.v26.i03.p08.

Chusnul, Chotimah. 2007. Analisis Faktor-Faktor yang Memengaruhi Kepatuhan Membayar Pajak Penghasilan Orang Pribadi (Survey di Kota Klaten). Skripsi. Universitas Muhammadiyah Surakarta.

Ezer, Eben. 2017. Pengaruh Tingkat Pendapatan, Tarif Pajak, Denda Pajak, dan Probabilitas Pemeriksaan Pajak Terhadap Kepatuhan Pajak. Diponegoro Journal of 
Accounting, 6 (3), 1-13.

Fernando, Fernando \& Anton Arisman. 2018. Pengaruh Sosialisasi Perpajakan, Pengetahuan Perpajakan, dan Sanksi Perpajakan Terhadap Kepatuhan Wajib Pajak Orang Pribadi (Studi Empiris Pada Wajib Pajak Orang Pribadi Yang Terdaftar Di KPP Pratama Palembang Seberang Ulu).Skripsi. STIE MDP.

Fuadi, Oentara Arabella dan Yenni Mangoting. 2013. Pengaruh Kualitas Pelayanan Petugas Pajak, Sanksi Perpajakan dan Biaya Kepatuhan Pajak Terhadap Kepatuhan Wajib Pajak UMKM. Tax and Accounting Review, 1(1), 60-65.

Ghozali, Imam. 2016. Aplikasi Analisis Multivariate Dengan Program IBM SPSS 21 (Edisi 8). Semarang : Badang Penerbit Universitas Diponorogo.

Handayani, I G.A. Ayu Ngr Adhi. 2009. Pengaruh Tanggung Jawab Moral dan Kualitas Pelayanan Terhadap Kepatuhan Pelaporan Wajib Pajak Badan pada Kantor Pelayanan Pajak Denpasar Barat. Skripsi. Jurusan Akuntansi Fakultas Ekonomi Universitas Udayana.

Hutagaol, John, Winarno, Wing Wanyu, dan Pradipta, Arya, 2007, Strategi Meningkatkan Kepatuhan Wajib Pajak. Jurnal Akuntabilitas, 6(2),186-193.

Julianto, A. 2017. Pengaruh Tarif, Sosialisasi serta Pemahaman Perpajakan terhadap Kepatuhan Wajib Pajak UMKM di Kota Semarang. Jurnal Ekonomi, 7 (1), hal. $67-76$

Kelley, Harold H. 1967. Attribution Theory in Social Psychology. Nebraksa Symposium on Motivation. 15, 192-238.

Kusumawati, Bunga Fitriana. 2016. Pengaruh Pemeriksaan Pajak, penagihan Pajak, Norma Moral dan kebijakan Sunset Policy terhadap Peningkatan Penerimaan Pajak (Studi Empiris pada Wajib Pajak Orang Pribadi di KPP Pratama Sleman). Diunduh dari Research Repository UMY website: http://repository.umy.ac.id/handle/123456789/7752.

Mandagi, dkk. 2015. Pengaruh Pemeriksaan Pajak terhadap Tingkat Kepatuhan Wajib Pajak Badan dalam Memenuhi Kewajiban Perpajakannya Pada KPP Pratama Manado. Jurnal EMBA, 3(2), 23-34.

Megantara, Kadek. 2017. Pengaruh Penghasilan Wajib Pajak, Sosialisasi Perpajakan, dan Kemauan Membayar Pajak terhadap Kepatuhan Wajib Pajak Usahawan atas Penerapan Peraturan Pemerintah Nomor 46 Tahun 2013 (Studi Pada Kantor Pelayanan Pajak Pratama Singaraja). Jurnal Ilmiah Akuntansi Undiksha, 7(1).

Mulyodiwarno, Nuryadi. 2007. Catatan Tentang Kebijakan Sanksi Perpajakan Sejak Undang-undang KUP 2007. Jakarta: Inside Tax

Mustikasari, Elia. 2007 . Kajian Empiris tentang Kepatuhan Wajib Pajak Badan di Perusahaan Industri Pengolahan di Surabaya. Simposium Nasional Akuntansi X:1- 


\section{Surabaya}

Oktaviani, Ristiana. 2014. Pengaruh Pemeriksaan Pajak, Pengenaan Sanksi Pajak dan Pemahaman Wajib Pajak terhadap Kepatuhan Wajib Pajak Pelaku UKM yang Terdaftar di KPP Pratama Karanganyar. Diunduh dari Research Repository UMS website: http://eprints.ums.ac.id/79781/

Palupi, Devy Yekti dan Eva Herianti. 2017. Pengaruh Pemeriksaan dan Penagihan Pajak terhadap Kepatuhan wajib Pajak dan Informasi Tren Media sebagai Variabel Moderating (Studi Kasus KPP Pratama Jakarta Kebayoran Baru Tiga). Jurnal Investasi, 13(1), 285-296

Peraturan Pemerintah No 23 Tahun 2018 tentang Pajak Penghasilan atas Penghasilan dari Usaha yang Diterima atau Diperoleh Wajib Pajak yang Memiliki Peredaran Bruto Tertentu.

Priliandani, N. M. I., \& Saputra, K. A. K. (2019). Pengaruh Norma Subjektif Dan Sosialisasi Perpajakan Terhadap Kepatuhan Wajib Pajak Hotel Dan Restoran. Krisna: Kumpulan Riset Akuntansi, 11(1), 13-25.

Rahayu, Siti Kurnia. 2013. Perpajakan Indonesia : Konsep dan Aspek Formal. Yogyakarta : Graha Ilmu.

Robbins, Stephen P. \& Judge, Timothy A. 2008. Perilaku Organisasi (Edisi ke-12). Jakarta: Salemba Empat.

Santi, Anisa Nirmala. 2012. Analisis Pengaruh Kesadaran Perpajakan, Sikap Rasional, Lingkungan, Sanksi Denda dan Sikap Fiskus Terhadap Kepatuhan Wajib Pajak (Studi Empiris pada WPOP di wilayah KPP Pratama Semarang). Skripsi. Fakultas Ekonomika dan Bisnis Universitas Diponegoro Semarang.

Sari, Andini Permata. 2018. Persepsi Tax Amnesty Sebagai Pemoderasi Pengaruh Kesadaran Wajib Pajak dan Sanksi Perpajakan pada Kepatuhan Wajib Pajak Orang Pribadi di Kantor Pelayanan Pajak Pratama Badung Utara. Skripsi. Fakultas Ekonomi dan Bisnis Universitas Udayana.

Sifanuri, Hana. 2017. Pengaruh Modernisasi Sistem Administrasi Perpajakan, Sosialisasi Perpajakan, Kesadaran Wajib pPajak, Sanksi Perpajakan Terhadap Kepatuhan Wajib Pajak (Studi Kasus Wajib Pajak Orang Pribadi Yang Memiliki Usaha Yang Terdaftar Pada KPP Purwokerto). Skripsi. Fakultas Ekonomi dan Bisnis Universitas Muhammadiyah. Purwokerto.

Sugiyono. 2017. Metode Penelitian Kuantitatif, Kualitatif, dan R\&D (Cetakan Ke-23). Bandung: Alfabeta.

Setyoningrum, Ayu Try. 2014. Analisis Pengaruh Sosialisasi Perpajakan, Kualitas Pelayanan Fiskus, dan Sanksi Perpajakan Terhadap Kepatuhan Wajib Pajak Orang Pribadi di Kantor Pelayanan Pajak Pratama Manado. Riset Akuntansi Going Concern, 9(4), 8-12

Sormin, Feber, Siti Sarpingah \& Riaty Handayani. 2017. Tax Obedience, Tax Knowledge, 
PP No.46, The Year of 2013, Personal Tax Payer With Certain Criteria, Small and Medium Size of Company (UMKM). Skripsi. Universitas Mercubuana.

Undang - Undang No. 20 Tahun 2008 tentang Usaha Mikro, Kecil, dan Menengah. Lembaran Negara RI Tahun 2008, No. 20. Sekretariat Negara. Jakarta

Undang - Undang Nomor 23 Tahun 2007 tentang Ketentuan Umum dan Tata Cara Perpajakan

Undang-Undang Nomor 36 Tahun 2008 tentang Pajak Penghasilan.

Undang-Undang Republik Indonesia Nomor 28 Tahun 2007 tentang Ketentuan Umum Dan Tata Cara Perpajakan. 